\title{
The incentives of households to implement the educational investment
}

\author{
Olga Nedospasova ${ }^{1}$, Ekaterina A. Taran ${ }^{1}$, and Ekaterina Anikina ${ }^{1, \mathrm{a}}$ \\ ${ }^{1}$ Tomsk Polytechnic University, 634050 Lenin Avenue, 30, Tomsk, Russia
}

\begin{abstract}
Households (as any other rational investors) will make investments in the higher education sphere only in case of being sure that in future invested money will generate a significant money flow at a low risk level. It is important that capital investment should bring return at the rate commensurable with profitability of other assets and time of their expenditure cover should not exceed the horizon, acceptable for the investor. In this article, indices of net present value (NVP) and a period of payback (PB) in the empirical case format are discussed in detail. A conclusion is made by empirical analysis about economic effectiveness of household investments in the higher education sphere and as a result, in personal human capital. The empiric case, presented in this article, revealed considerable private economic benefits from higher education.
\end{abstract}

\section{Introduction}

When analyzing investment solutions of households one should act on the premise that for them investments in the higher professional education (HPE) sphere, as any kinds of investing, have the following important characteristics:

- significant financial expenditure;

- investment profits only in future;

- forecasting of investment results in risk and uncertainty conditions.

According to the general definition, investments are expenditures of «today» supposing «future» benefits, therefore total costs of HPE must be compared with expected income of a higher education bearer in future, when efficiency of household education investments is evaluated. In the frames of the investment approach the following criterion of household investment efficiency in higher education can be formulated: total income in future, due to higher education, must considerably exceed total expenditure to get it. In this case, from the viewpoint of a HPE bearer, investing will be effective. This approach help calculate corresponding values of main indicators of investment efficiency.

\section{Results and discussion}

Indices of net present value (NVP) and a period of payback (PB) in the empirical case format are discussed in detail in this article. It is known that such research helps study a present day phenomenon in its really existing context [1]. The choice of an empirical case for economic effectiveness evaluation of education investments gives a possibility to make conceptual conclusions, providing not only the understanding of events, but their practical application as well.

Investment efficiency analysis in the HPE sphere from household positions can be divided into three stages:

- identification of total income due to getting this level of education and cost evaluation with the time factor taken into account;

- expenditure identification and cost evaluation to get HPE;

- comparison of income and expenditure flows.

As a result of this succession, net profit formation (future income excess over preceding expenditure) assumes using discount criteria. Discounting is based on the statement that future money income has less value at present. A numerical expression of time value of money is a percent rate (discount), showing a relative change of money value per time unit.

A bearer of higher education, when estimating its economic value, inevitably has impediments in determining a discount rate. Every household has individual ideas about base income rates in economy and orientates to the dynamics of the main world currency course in relation to the Russian rouble, an income rate in deposits for individuals of reliable banks, etc. In this article the consumer price index (CPI) is chosen as a discount standard and a conservative income/profit value of alternative investments, taking into account potential risks of the process. Mind that this level is more than 3 times higher than the analogous indicator used to estimate investment efficiency in higher education in OECD countries, that reflects significant difference in

\footnotetext{
a Corresponding author: anikinaea@tpu.ru
} 
stability of the macroecnomic situation in Russia and economically developed countries.

High wage of higher education bearers is an important stimulus for individual investments in this sphere. As a result of getting education, income (with discounting, that decreases future profit) must considerably exceed a corresponding total of investment. Thus, investing in HPE is profitable, if net discounted income (NPV) from higher education investment (calculated as a sum of discounted net effective money flows over the whole period of consideration) is not negative.

$$
N P V=D_{0}+\frac{D_{1}}{1+d}+\frac{D_{2}}{(1+d)^{2}}+\frac{D_{3}}{(1+d)^{3}}+\ldots+\frac{D_{n}}{(1+d)^{n}}-C \geq 0,
$$

where:

$\mathrm{C}$ - investing in human capital;

Dn - flow current value of future additional income;

$\mathrm{d}$-discount standard; $\mathrm{n}$ - years, analysis horizon

To estimate economic investment effectiveness of households in getting HPE, it is necessary to calculate a sum income of its future bearer, supposing her/his employment in national economy after graduation. For cost evaluation of potential income, it is necessary to take into account wage differences among categories of employees, having different levels of education.

The analysis of economic investment effectiveness of households in HPE, given in this article, is based on the fact, that in Russia the income level of a person, in most cases, is determined by the education level. To show the income dependence on having a HPE diploma, in this research the average nominal real wages in Russian Federation are compared. The comparison is conducted according to positions and functions, in addition corrected to the factor, considering the wage increase depending on the education level and subsistence minimum as a conservative value of the potentially possible wage level of persons not having higher education. Data covering the period of up to 2008 were used. Such limitation in the investment horizon is reasonable as it prevents results from being distorted because of negative influence of the global economic crisis.

At the preliminary stage of the analysis there was lack of statistic data according to education levels of human resources in the economy sphere. Therefore, data about average nominal real wages according to positions of workers were used, implying $100 \%$ correspondence of professional requirements and the education level (for instance: foreman, engineer - higher education; engine driver, machine operator - secondary special education; mason, carpenter - primary professional education; laboratory assistant, operator - compulsory secondary education). A similar approach is rather distributed in domestic practice and successfully applied in economic substantiation of human capital accumulation, for example, in works of professor I. A. Maiburov [2,3].

Further, according to official statistic data in main economy sectors, the analysis of differences in the wage level of people without higher education (having worker specialities) and people who have got HPE (working as specialists) was made [4]. The analysis of results revealed sufficiently steady interdependence of wages and the education level of workers in Russia (in spite of essential branch differences). At present, the wage increase in accordance with the education level varies from 118 to $161 \%$, and the average increase is $32 \%$ in Russia (Table1).

Table 1. An average charged wage of workers in organizations according to economic activities, roubles.

\begin{tabular}{|c|c|c|c|}
\hline Economic activities & Personnel & Workers & $\begin{array}{c}\text { Wage } \\
\text { increase in } \\
\text { accordance } \\
\text { with the } \\
\text { education } \\
\text { level } \\
(1 / 2), \%\end{array}$ \\
\hline & 1 & 2 & 3 \\
\hline Extraction of minerals & 33725 & 22476 & 150 \\
\hline $\begin{array}{l}\text { including: } \\
\text {-fuel and energy } \\
\text { resources; }\end{array}$ & 37688 & 24711 & 153 \\
\hline $\begin{array}{l}\text {-extraction of } \\
\text { minerals except fuel and } \\
\text { energy resources }\end{array}$ & 21635 & 17777 & 122 \\
\hline Manufacturing sectors & 16072 & 12864 & 125 \\
\hline $\begin{array}{l}\text { including: } \\
\text { - food } \\
\text { production including } \\
\text { beverage and tobacco; }\end{array}$ & 17277 & 11174 & 155 \\
\hline $\begin{array}{l}\text { - textile and clothing } \\
\text { manufacture }\end{array}$ & 10754 & 7597 & 142 \\
\hline $\begin{array}{l}\text { - leather, leather items, } \\
\text { footwear production; }\end{array}$ & 12027 & 9300 & 129 \\
\hline $\begin{array}{l}\text { - woodworking and } \\
\text { woodwork items } \\
\text { production; }\end{array}$ & 14235 & 10985 & 130 \\
\hline $\begin{array}{l}\text {-pulp and paper } \\
\text { production; publishing } \\
\text { and printing activity; }\end{array}$ & 18882 & 13071 & 144 \\
\hline $\begin{array}{l}\text { - coke and petrochemical } \\
\text { products manufacture; } \\
\text { chemical production; } \\
\text { rubber and plastic items } \\
\text { production; }\end{array}$ & 19060 & 13590 & 140 \\
\hline $\begin{array}{l}\text { - other nonmetal mineral } \\
\text { products manufacture; }\end{array}$ & 16268 & 13255 & 123 \\
\hline $\begin{array}{l}\text { - metallurgical production } \\
\text { and metal items } \\
\text { production }\end{array}$ & 17867 & 15519 & 115 \\
\hline $\begin{array}{l}\text {-machinery and } \\
\text { equipment production; }\end{array}$ & 16274 & 13369 & 122 \\
\hline $\begin{array}{l}\text { - electrical, electronic and } \\
\text { optical equipment } \\
\text { production; }\end{array}$ & 13591 & 11548 & 118 \\
\hline -other manufacturing. & 15266 & 12037 & 127 \\
\hline $\begin{array}{l}\text { Electricity, gas and water } \\
\text { production and } \\
\text { distribution }\end{array}$ & 19645 & 12208 & 161 \\
\hline Weight average & 17607 & 13307 & 132 \\
\hline
\end{tabular}

These data were taken for the subsequent efficiency evaluation of household investing in HPE to identify income of higher education bearers. It must be mentioned that in the considered empirical case, a subsequent income increase due to work experience improvement, professional development, occupational 
retraining or getting additional education (for instance, second higher education) were not taken into account.

Data of official statistics were also used for calculations [5]. The calculation of the expected wage of the HPE graduate on the basis of the average nominal charged wage with the updating of income increase according to the education level was made. The wage of school leavers was determined at the level of subsistence minimum in the corresponding period.

In terms of these calculations, corresponding excess values of the HPE graduates wage over the school leavers wage were determined, then discounting of these results was carried out and an expected sum of inflows from HPE with increasing total for the period of 20092012 was calculated.

When evaluating total expenditure for getting HPE, not only explicit costs, as agreed cost of paid educational services, but implicit costs as well were taken into account, the latter characterizing:

- missed earnings during years of studies;

- lost income from alternative investments of households.

In this research, due to the fact that there are no reliable data about «missed» earnings of students in Russia and a student, as a former school student, has no special education and qualification, the value of subsistence minimum level in the corresponding period was taken as the indicator analogue, characterizing missed earnings of students during study years. It is important to note that such value is, to a large extent, conservative, as it does not take into consideration possibilities of undergraduates to combine study and work, to earn money during holidays that can be much higher than official data about subsistence minimum.

Missed investment income of households (as an element of implicit costs), in its turn, can be evaluated as potential interest income from money spent to pay for higher education [6]. Proceeding from conservative values, minimal profitability of alternative investments can be estimated at the CPI level for corresponding periods.

In Table 2 calculation results about total spending of households due to getting HPE are shown. Data presented in the table and all calculations of efficiency of corresponding investment in personal human capital were carried out by example of a secondary school leaver, getting higher education at Seversk Technological institute - a branch of National research nuclear university «MIFI» on terms of full education cost payment.

Table 2. Household expenditure due to getting HPE, roubles.

\begin{tabular}{|c|l|l|l|l|l|}
\hline $\mathbf{N}$ & Indicators & $\mathbf{2 0 0 5}$ & $\mathbf{2 0 0 6}$ & $\mathbf{2 0 0 7}$ & $\mathbf{2 0 0 8}$ \\
\hline 1 & Explicit cost & 30000 & 34800 & 38300 & 46000 \\
\hline 2 & $\begin{array}{l}\text { Subsistence } \\
\text { minimum (per } \\
\text { year) }\end{array}$ & 36216 & 41064 & 46176 & 54708 \\
\hline 3 & $\begin{array}{l}\text { CPI (in \% to } \\
\text { the level of a } \\
\text { previous year) }\end{array}$ & 110.9 & 109.0 & 111.9 & 113.3 \\
\hline 4 & Missed & 3270 & 3132 & 4558 & 6118 \\
\hline
\end{tabular}

\begin{tabular}{|c|c|c|c|c|c|}
\hline & $\begin{array}{l}\text { income from } \\
\text { alternative } \\
\text { investment } \\
(\mathrm{N} 1 \times(\mathrm{N} 3- \\
100) / 100)\end{array}$ & & & & \\
\hline 5 & $\begin{array}{l}\text { Implicit cost } \\
(\mathrm{N} 2+\mathrm{N} 4)\end{array}$ & 39486 & 44196 & 50734 & 60826 \\
\hline 6 & $\begin{array}{l}\text { Total } \\
\text { spending } \\
\text { (N1+ N5) }\end{array}$ & 69486 & 78996 & 89034 & 106826 \\
\hline 7 & $\begin{array}{l}\text { General costs } \\
\text { with } \\
\text { increasing } \\
\text { total }\end{array}$ & 128157 & 207153 & 296187 & 403013 \\
\hline
\end{tabular}

Thus, the total calculated NPV value is positive, 380870 roubles. This means that household investments in HPE are economically profitable, the flow of future additional income (with its discounting) significantly exceeds investments in higher professional education, forming net profit for its bearer.

To determine the payback time of household investments in HPE, total outflows due to getting higher education were brought into correlation with corresponding values of inflows (annual income of a specialist with higher education in her/his first year of work). The index of number of years required to return money invested by households in HPE equals 1,8 years. If the investment period duration (five years of education at a higher school at a day-time department according a specialization program) is added to this value, payback time of education investments, i.e. number of years, required to return money invested by households in HPE is about 7 years since the beginning of studies at a higher school.

\section{Conclusion}

To sum up, the empirical analysis confirmed the assumption about economic effectiveness of household investments in the HPE sphere and as a result, in personal human capital. The following conclusions, based on the analysis results, corroborate this:

1. the income of HPE bearers considerably exceeds spending to get it;

2. the payback time of household investments in HPE (by the example of Seversk Technological institute, a branch of National research nuclear university MIFI) does not exceed 7 years and allows valuing this kind of investments as medium-term ones, consequently, less risky than investments in more prolonged investing projects or other assets;

3. taking into account that about a quarter of GDP of Russia is produced in shadow economy and a large part of real wage is not registered in official statistics, actual indices of education investment efficiency may be much higher than conservative values received in this research, and payback time may be shorter;

4. as, in average, work experience of a specialist having HPE is about 40 years in Russia, such specialist can work «for herself/himself» for more than 30 years, reaping the fruits of studies at a higher education institution and getting net profit from education investment. This conforms to conclusions of experts that 
at present in Russia, as in the majority of developing countries, private gains from getting higher education grow faster than private expenditures.

It should be noted that, if a big part of education expenditures is covered by the state, individuals have natural desire to get these benefits in maximum quantity regardless of their return conditions. However, if state and private co-financing of these expenditures, as investment in human capital, occurs, potential of investment activity of subjects, forming a corporative economy sector may be widened [7].

The empiric case, presented in this article, revealed considerable private economic benefits from higher education. Though this method has inherent local variability, its results prove that HPE not only influences a social status of a person significantly, but it is of individual benefit, supplying its bearers with the inflow of considerable economic advantages. This allows concluding that, a traditional idea about higher education as the social good, which is a peculiar characteristic of various economy schools of the past, is changed into the idea that it is a private good.

Thanks to arguments of Chicago School representatives (starting with Milton Friedman) and London School of economy, experts of the World Bank, views at higher education as an important sphere of private economic interests become a postulate in sociopolitical circles all over the world (some exceptions in Scandinavian countries). Thus, information given in this work is a powerful signal, motivating private investors (not only households, but also a corporative sector as well) to make preferences to invest in human capital instead of current consumption.

However, for the signal to find its embodiment in large-scale growth of education investments, private economic stimuli must be conformed to investment priorities of state social policy. Possibilities of the public-private partnership are of great importance as an institutional and organizational alliance of state and private sectors of economy with the purpose to realize social-important projects in a wide spectrum of activity spheres.

Under conditions of the public-private partnership, multi-subject investments in the higher education sphere have a great potential to their transformation into new human capital, corresponding to fundamental requirements of innovation development of economy. Practical realization of this idea requires a strategic approach to multi-subject investment in human capital saving. Due to this, there is a possibility for correct substantiation of state and non-state investing shares in the HPE sphere. These shares are proportional to benefits, which will be given to each partner in the public-private partnership in future.

\section{Acknowledgment}

The authors acknowledge the financial support from the Russian Humanities Research Foundation Project 'Availability of tertiary education and its quality improvement under innovative reconstruction in Russia' (project № 14-32-01043a1).

\section{References}

1. R.K. Yin, Applied Social Research Methods Series, 5, 23 (1989)

2. I. Mayburov, SE, 7-8, 45 (2006)

3. I. Mayburov, WE\&IR, 4, 32 (2004)

4. Russian Industry - 2008 (2008)

5. Russia in Figures - 2008 (2009)

6. E. Anikina, L. Ivankina, E. Taran, Innovation Management and Sustainable Economic Competitive Advantage: From Regional Development to Global Growth, 1231 (2015)

7. E. Anikina, L. Ivankina, I. Tumanova, Procedia Social and Behavioral Sciences, 166, 48 (2015) 